\title{
Somatic embryogenesis in loblolly pine (Pinus taeda L.): improving culture initiation rates
}

\author{
Gerald S. Pullman* and Shannon Johnson \\ Institute of Paper Science and Technology, 500 10th Street, Atlanta, GA 30318, USA
}

(Received 5 July 2001; accepted 5 February 2002)

\begin{abstract}
Loblolly pine (Pinus taeda L.) is one of the most important commercial trees in the U.S. To be successful for commercial use, somatic embryogenesis technology must work with a variety of genetically diverse seeds. Initiation rates of loblolly pine were improved through a combination of modified 1/2 P6 salts, activated carbon at 50-100 $\mathrm{mgL}^{-1}, \mathrm{Cu}$ and $\mathrm{Zn}$ added to compensate for adsorption by activated carbon, $1.5 \%$ maltose, $2 \%$ myo-inositol, (to raise osmotic level partially simulating the ovule environment), $500 \mathrm{mg} \mathrm{L}^{-1}$ case amino acids, $450 \mathrm{mg} \mathrm{L}^{-1}$ glutamine, $2 \mathrm{mg} \mathrm{L}^{-1} \mathrm{NAA}, 0.45 \mathrm{mg} \mathrm{L}^{-1} \mathrm{BAP}, 0.43 \mathrm{mg} \mathrm{L}^{-1}$ kinetin, and $1.6-2 \mathrm{~g} \mathrm{~L}^{-1}$ Gelrite. Across 10 open-pollinated families, initiation rates ranged from $3-33 \%$, averaging $16 \%$.
\end{abstract}

Loblolly pine / somatic embryogenesis / initiation / conifer / Pinus taeda

Résumé - Embryogenèse somatique de Pinus taeda L. : amélioration du taux d'initiation des cultures. Pinus taeda L. est l'une des plus importantes espèces commerciales aux États-Unis d'Amérique. Pour être exploitable à un niveau commercial, l'embryogenèse somatique doit s'appliquer sur une grande variété de graines génétiquement diverses. Les taux d'initiation de cultures embryogènes de Pinus taeda ont été améliorés grâce à l'association des éléments suivants : sels du milieu P6 dilué de moitié, charbon actif à la dose de 50 à 100 mg L ${ }^{-1}$ (avec adjonction de $\mathrm{Cu}$ et $\mathrm{Zn}$ pour compenser leur adsorption par le charbon actif), 1,5\% de maltose, $2 \%$ de myo-inositol (pour augmenter la pression osmotique, simulant partiellement le développement de l'ovule), $500 \mathrm{mg} \mathrm{L}^{-1}$ d'acides aminés provenant d'hydrolyse acide de caséine, $450 \mathrm{mg} \mathrm{L}^{-1}$ de glutamine, $2 \mathrm{mg} \mathrm{L}^{-1} \mathrm{~d}$ 'acide naphtalène acétique, $0,45 \mathrm{mg} \mathrm{L}^{-1}$ de benzylaminopurine, $0,43 \mathrm{mg} \mathrm{L}^{-1}$ de kinétine et 1,6 à $2 \mathrm{mg} \mathrm{L} \mathrm{L}^{-1}$ de Gelrite. Dans ces conditions, les taux d'initiation varient pour les 10 descendances maternelles étudiées de 3 à $33 \%$, avec une moyenne de $16 \%$.

Pinus taeda / embryogenèse somatique / initiation / conifère

\section{INTRODUCTION}

Conifer somatic embryogenesis (SE) has been demonstrated for many genera [7, 14, 20, 21]. SE proceeds through initiation, multiplication, maturation, and germination. A cryogenic storage step may be added when storage of embryogenic cultures is desired. The first report of SE in loblolly pine (LP) (Pinus taeda L.) occurred in 1987 [8]. Since then several reports have focused on LP along with abundant patent activity [3, 18]. Factors currently limiting commercialization of SE for LP include low initiation rates (many desirable genotypes are recalcitrant), low culture survival, culture decline causing low or no embryo production, and the inability of somatic embryos to fully mature resulting in low germination and slow initial growth of somatic seedlings.

Reports on initiation of LP embryogenic tissue indicate initiation frequencies of $1-5 \%$ [1, 3, 8, 12, 13]. Several patents contain methods for improved initiation frequencies for LP $[2,10,11]$. These low levels have provided a block for the scientific and commercial use of SE to multiply valuable LP genotypes. To capture the gains of long-term LP breeding programs, clonal propagation methods must work on a wide range of genotypes.

Activated carbon (AC) improved initiation in radiata pine and embryo development in Douglas-fir [16, 19]. Since AC may adsorb $95-99 \%$ of the plant growth regulators (PGR)

* Correspondence and reprints

Tel.: (404) 894 5307; fax: (404) 894 4778; e-mail: Jerry.Pullman@ipst.edu 
present in tissue culture media $[5,6,16]$, we began to test initiation media with greatly increased levels of PGR combined with $2.5 \mathrm{~g} \mathrm{~L}^{-1} \mathrm{AC}$. Statistically significant increases in ovule extrusion occurred when $\mathrm{AC}$ was added to the initiation medium; however, only a few initiations resulted. Toering (1995) [24] tracked the availability of 2,4-dichlorophenoxyacetic acid $(2,4-D)$ in initiation media using radiolabeled 2,4-D. Media with $2.5 \mathrm{~g} \mathrm{~L}^{-1} \mathrm{AC}$ and $220 \mathrm{mg} \mathrm{L}^{-1}$ 2,4-D contained $12-17 \mathrm{mg} \mathrm{L}^{-1}$ available 2,4-D during much of the initiation period. These findings suggested two approaches to improve initiation media: (1) lower 2,4-D from 220 to $110 \mathrm{mg} \mathrm{L}^{-1}$ in the presence of $2.5 \mathrm{~g} \mathrm{~L}^{-1} \mathrm{AC}$; or (2) greatly reduce AC levels and combine with standard or slightly raised PGR levels similar to levels used in media without AC.

When somatic embryos from suspension cultures were placed on initiation media without AC they grew well; however, when media contained $2.5 \mathrm{~g} \mathrm{~L}^{-1} \mathrm{AC}$ growth was reduced. This observation suggested that AC adsorbs a required media component or adds a toxic component to the medium. With this working hypothesis, media mineral components + - AC were analyzed $[17,25]$ and $\mathrm{AC}$ at $2.5 \mathrm{~g} \mathrm{~L}^{-1}$ was found to reduce $\mathrm{Cu} 90 \%$ and $\mathrm{Zn} \mathrm{50 \% .}$

The focus of the research in this report was the development of a somatic embryogenesis (SE) initiation system that would work across a diversity of genetic material of Pinus taeda. Measurements of ovule water potential during early embryo growth and availability of ions and PGR in tissue culture media containing AC provided clues for SE initiation improvements. Simulated initiation tests using single somatic embryos as explants were used to test potential medium improvements and zygotic embryo initiation tests verified improvements.

\section{MATERIALS AND METHODS}

\subsection{Plant materials}

\subsubsection{Zygotic embryos}

Loblolly pine cones were collected weekly in early to mid-July 1993-1998 from open-pollinated trees in clonal seed orchards, shipped on ice, and received within 24-48 hours. Collections also occurred in mid-January by Westvaco Corp./Rigesa, Celulose from breeding orchards near Canhinhas, Santa Catarina, Brazil. Cones were stored at $4-5{ }^{\circ} \mathrm{C}$ for $1-9$ weeks.

Cones containing seeds with embryos mostly at stages 2-4 [18] were used for initiation tests. Cones were opened and seeds separated from the ovuliferous scales. Seeds were washed in running cold tap water for $10 \mathrm{~min}$, agitated for $10 \mathrm{~min}$ in $10 \%$ liquinox (detergent) containing $2 \mathrm{~mL}$ Tween $20 \mathrm{~L}^{-1}$, rinsed for 30 min with running tap water, agitated for 10 min aseptically in $20 \%(\mathrm{v} / \mathrm{v})$ hydrogen peroxide, and rinsed five times with sterile deionized water. Dissection: seeds were cracked using a hemostat, pried open with the aid of forceps and a scalpel, and the seed coat, integument and nucellus were removed from the ovule (megagametophyte).

\subsubsection{Somatic embryos}

Somatic embryos were also used as explants for experiments. Cultures of somatic embryos were multiplied in liquid medium 16 [18]. Single stage 2 embryos were isolated with forceps from suspension culture and placed on test initiation medium, grown for 4-7 weeks, and measured for resulting embryogenic tissue diameters. Thirty or forty single somatic embryos were evaluated on test media arranged in three or four replicates of ten embryos each. Single somatic embryo explants provided a measurement of a medium's potential to support the last phase of initiation and multiplication of the somatic embryos into an embryogenic culture mass.

\subsection{Media and Culture Conditions}

Medium most often consisted of modified 1/2 P6 Salts [9], a modification of P6 from Teasdale et al. 1986 [22]. Acid-washed tissue culture tested AC (Sigma, C9157) was used in media containing $\mathrm{AC}$. The $\mathrm{pH}$ of medium was adjusted with $\mathrm{KOH}$ or $\mathrm{HCl}$ after the addition of all ingredients except gelling agent or filter-sterilized materials. Gelling agent was added prior to autoclaving at $121^{\circ} \mathrm{C}$ for $20 \mathrm{~min}$. Aqueous stock solutions of L-glutamine or filter-sterilized materials were added to medium cooled to approximately $55^{\circ} \mathrm{C}$. Maltose was used as a carbon source and medium was gelled with $1.6-4 \mathrm{~g} \mathrm{~L}^{-1}$ gellan gum. Two \% myo-inositol was included in media to raise osmolality from approximately 160 to $225 \mathrm{mmol} \mathrm{kg}^{-1}$ based on measured water potential of developing LP ovules [15]. Explants were cultured on $2 \mathrm{~mL}$ of medium contained in individual wells of Costar \#3526 Well Culture Cluster Plates. Petri dishes and well plates were wrapped in two layers of Parafilm and incubated at $23-25{ }^{\circ} \mathrm{C}$ in the dark.

\subsection{Extrusion and initiation success and statistical analysis}

Initiation occurs in three steps. Within 1-4 weeks extrusion occurs when one or more zygotic embryos push out of the megagametophyte micropylar end and become visible protruding from the gametophyte or on the medium. At 5-7 weeks somatic embryos begin to form on the zygotic embryos. Somatic embryos then continue the multiplication process to form a mass of embryogenic tissue. These phases can be evaluated as \% extrusion, \% explants forming three or more somatic embryos (visible through a dissecting microscope), and \% explants achieving a target mass or size. Percent extrusion and explants with three or more somatic embryos visible were routinely evaluated 9-10 weeks after placement of ovules on media. Treatments were arranged in a completely randomized design. Data were analyzed by analysis of variance and significant differences between treatment means were determined by the Duncan Multiple Range Test at the 5\% level of significance.

\subsection{Adjustment of copper and zinc compensating for $\mathrm{AC}$ adsorption}

Medium 288 (table I) was prepared and $\mathrm{Cu}$ sulfate adjusted to 0.125 (medium 288), $0.25,0.375,0.5,1.0$, and $2.5 \mathrm{mg} \mathrm{L}^{-1}$. Thirty somatic embryos from each of three genotypes were placed on test medium as described earlier. After seven weeks tissue diameters were measured. 
Table I. Media components for experiment varying activated carbon.

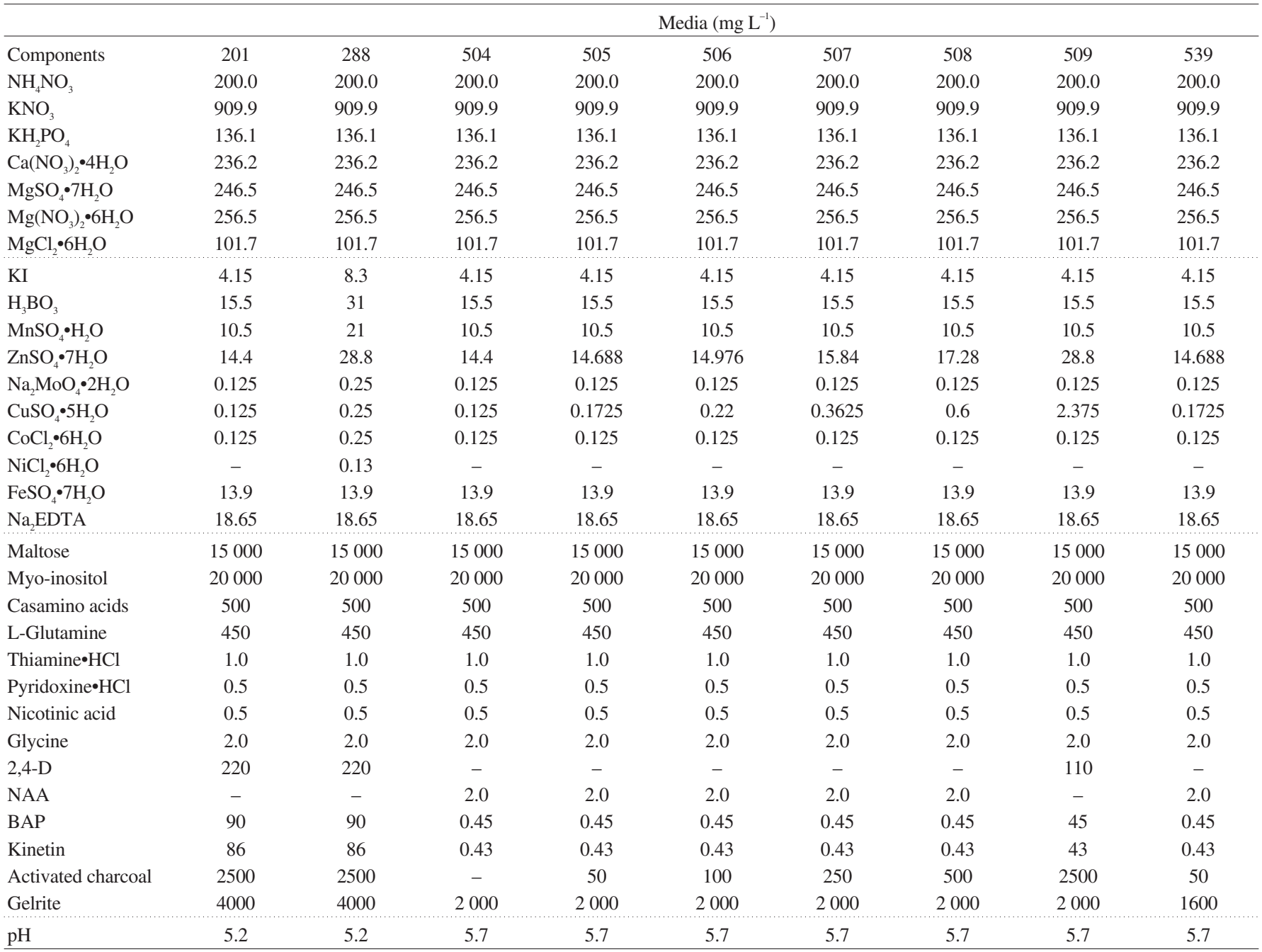

Inductively coupled plasma (ICP) atomic emission spectroscopy for $\mathrm{Zn}$ and graphite furnace atomic adsorption for $\mathrm{Cu}$ were performed on six media that were adjusted for initial $\mathrm{Cu}$ and $\mathrm{Zn}$ levels. Medium 201 (table I) was modified by the addition of $0.13 \mathrm{mg} \mathrm{L}^{-1}$ $\mathrm{NiCl}_{2} \cdot 6 \mathrm{H}_{2} 0$, adjustment of zinc sulfate to $57.6 \mathrm{mg} \mathrm{L}^{-1}$, and adjustment of copper sulfate to $0.25,1.0,2.5,5.0$, and $10 \mathrm{mg} \mathrm{L}^{-1}$. Control medium had no AC, copper sulfate and zinc sulfate at 0.125 and $14.4 \mathrm{mg} \mathrm{L}^{-1}$, and 2,4-D, BAP, and Kinetin reduced to $1.1,0.45$, and $0.43 \mathrm{mg} \mathrm{L}^{-1}$, respectively. Three replicates of ten $\mathrm{ml}$ per test medium were filtered through a $0.22 \mu \mathrm{m}$ cellulose acetate membrane to collect liquid for analysis on days 14 and 28 to determine if $\mathrm{Cu}$ and $\mathrm{Zn}$ were further adsorbed. A water control was included for reference.

\subsection{Initiation from ovule explants in media containing low amounts of activated carbon}

AC was varied from 0 to $500 \mathrm{mg} \mathrm{L}^{-1}$ using PGR levels at $2 \mathrm{mg} \mathrm{L}^{-1}$ NAA, $0.45 \mathrm{mg} \mathrm{L}^{-1} \mathrm{BAP}$, and $0.43 \mathrm{mg} \mathrm{L}^{-1}$ Kinetin, adding extra $\mathrm{Cu}$ and $\mathrm{Zn}$, and $2 \mathrm{~g} \mathrm{~L}^{-1}$ gellan gum (table I, media 504-508). A control medium containing $2.5 \mathrm{~g} \mathrm{~L}^{-1} \mathrm{AC}$ with raised hormones, $\mathrm{Cu}$, and $\mathrm{Zn}$ was also included (table I, medium 509). Thirty ovules (three replicates of ten) from each of three cone collections and thirty somatic embryo explants were placed on each test medium.

With the positive effects evident for low AC combined with $2 \mathrm{~g} \mathrm{~L}^{-1}$ gellan gum, NAA, and $\mathrm{Cu}$ and $\mathrm{Zn}$ adjusted for AC adsorption, we next wanted to determine the optimal gellan gum level. Components in medium 505 (table I) were held constant and gellan gum was varied from $0-4 \mathrm{~g} \mathrm{~L}^{-1}$. A control medium with $2 \mathrm{~g} \mathrm{~L}^{-1}$ Gelrite and no AC was also included (medium 504, table I). Thirty ovule explants (three replicates of ten) from each of three cone collections were placed on each test medium. Ovules in liquid media were placed on presterilized $3-\mathrm{cm}$ squares of polyester batting covered with a $4.25-\mathrm{cm}$ circle of Ahlstrom Black Filter Paper Grade 8613 contained in $60 \times 15 \mathrm{~mm}$ Petri plates.

\subsection{Initiation rates and culture survival for multiple families}

Cultures initiated on media 505 and 539 were maintained on medium 16 [18] with the addition of $2.5 \mathrm{~g} \mathrm{~L}^{-1}$ gellan gum. Embryogenic tissue was subcultured every two weeks. Tissue masses about one 
$\mathrm{cm}$ in diameter were divided into $2-3$ parts at the beginning of each subculture. After six months data were collected on the number of cultures actively growing. Active growth was determined by marking the colony edge at the time of transfer and visually determining at the end of the subculture cycle if the colony size increased.

\section{RESULTS}

\subsection{Adjustment of copper and zinc compensating for AC adsorption}

Tests with single somatic embryos grown on initiation medium showed a strong effect of medium $\mathrm{Cu}$ content on growth into masses of embryogenic tissue. Colony size increased with increasing $\mathrm{Cu}$ concentration in medium supplemented with $2.5 \mathrm{~g} \mathrm{~L}^{-1} \mathrm{AC}$ (figure 1). Activated carbon in the initiation medium likely adsorbed $\mathrm{Cu}$ ions resulting in $\mathrm{Cu}$ deficiency. Supplementing medium with extra $\mathrm{Cu}$ compensated for the adsorbed $\mathrm{Cu}$ removing the deficiency.

In general, free $\mathrm{Cu}$ and $\mathrm{Zn}$ levels rose when the initial concentrations were increased (figure 2). Adding $2.5 \mathrm{mg} \mathrm{L}^{-1}$ (20 times the original amount) of $\mathrm{CuSO}_{4} \cdot 5 \mathrm{H}_{2} \mathrm{O}$ to charcoal-containing medium duplicated the level of free $\mathrm{Cu}$ available in medium without charcoal. When the initial $\mathrm{Zn}$ level was quadrupled, it more than compensated for the adsorption by AC. Doubling the $\mathrm{ZnSO}_{4} \cdot 7 \mathrm{H}_{2} \mathrm{O}$ to $28.8 \mathrm{mg} \mathrm{L}^{-1}$ would

\section{$\mathrm{CuSO}_{4} 5 \mathrm{H}_{2} \mathrm{O}$ Concentration vs. Colony Diameter}

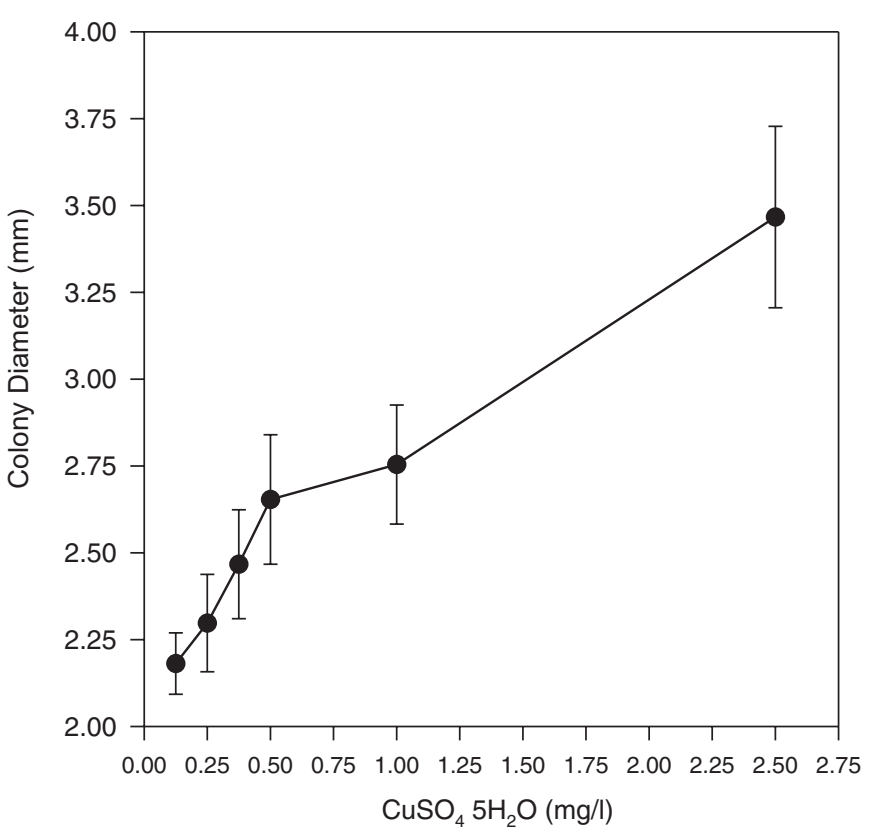

Figure 1. Effect of initial copper sulfate concentration on growth of single somatic embryos into embryogenic tissue masses. Medium contained $2.5 \mathrm{~g} \mathrm{~L}^{-1}$ of activated carbon. Standard error bars are shown for growth at each copper concentration.
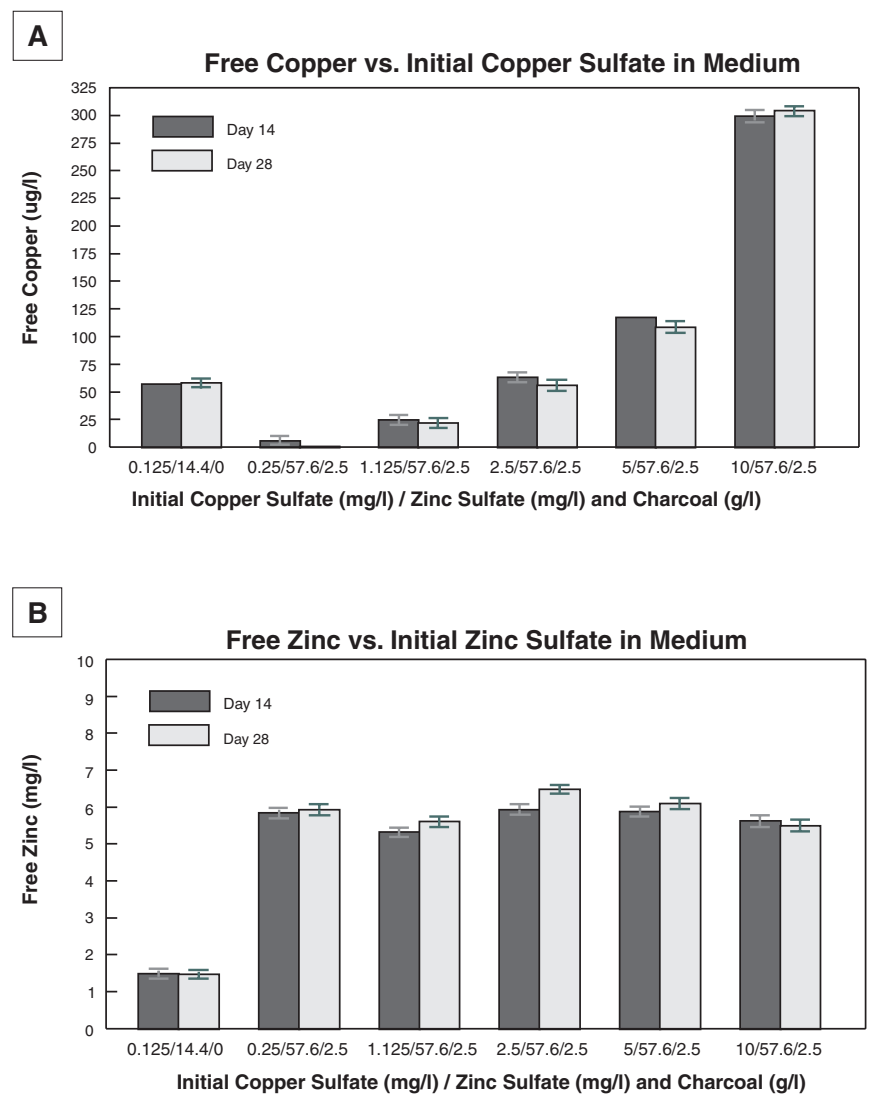

Figure 2. Effect of five copper sulfate/zinc sulfate and two charcoal concentrations on the amount of: (A) free copper $\left(\mu g \mathrm{~L}^{-1}\right)$ and (B) free zinc $\left(\mathrm{mg} \mathrm{L}^{-1}\right)$ that is available in medium. Standard error bars are shown for each triplicate analyses.

probably result in the desired level available in media without AC. There was little difference in $\mathrm{Cu}$ or $\mathrm{Zn}$ after 14 vs. 28 days.

\subsection{Initiation from ovule explants in media containing low amounts of activated carbon}

Medium containing $50-100 \mathrm{mg} \mathrm{L}^{-1}$ AC supported the highest ovule extrusion rates (table II). While statistically significant differences did not occur for initiation rates per medium, a trend was suggested for improved extrusion and initiation with lower levels of AC. Medium 505 produced $3-10 \%$ SE initiation across three cone collections. Growth of single somatic embryos on test initiation media also supported this observation (table II) by being greatest on medium 505 (50 $\mathrm{mg} \mathrm{L}^{-1} \mathrm{AC}$ ) and worst on medium 504 (no AC).

Results from varying the gellan gum level in medium 505 are shown in table III. Extrusion \% and initiation \% increased as the gelling agent increased from none to $2 \mathrm{~g} \mathrm{~L}^{-1}$. Peak extrusion and initiation occurred at $2 \mathrm{~g} \mathrm{~L}^{-1}$ (medium 505). Ovules on liquid medium ( $0-0.25 \mathrm{~g} \mathrm{~L}^{-1}$ gellan gum) showed the lowest extrusion and initiation rates. 
Table II. Extrusion and initiation on media containing low activated carbon levels.

\begin{tabular}{|c|c|c|c|c|c|c|c|}
\hline \multirow[t]{2}{*}{ Media } & \multirow{2}{*}{$\begin{array}{c}\text { Activated carbon } \\
\mathrm{mg} \mathrm{L}^{-1}\end{array}$} & \multirow{2}{*}{$\begin{array}{c}\text { Extrusion } \\
\text { Average* } \\
(\%)\end{array}$} & \multicolumn{4}{|c|}{ Seed source and initiation } & \multirow{2}{*}{$\begin{array}{c}\begin{array}{c}\text { Embryogenic } \\
\text { tissue growth }\end{array} \\
\begin{array}{c}\text { Colony diameter* } \\
(\mathrm{mm})\end{array}\end{array}$} \\
\hline & & & UC 10-33 & $\mathrm{BC} 2$ & UC $10-5$ & $\begin{array}{l}\text { Average* } \\
(\%)\end{array}$ & \\
\hline 504 & 0 & $18.9 \mathrm{a}$ & $2 / 30$ & $0 / 30$ & $0 / 30$ & $2.2 \mathrm{a}$ & $3.9 \mathrm{a}$ \\
\hline 505 & 50 & $33.3 \mathrm{~b}$ & $1 / 30$ & $3 / 30$ & $1 / 30$ & $5.6 \mathrm{a}$ & $10.1 \mathrm{c}$ \\
\hline 506 & 100 & $25.6 \mathrm{ab}$ & $1 / 30$ & $1 / 30$ & $2 / 30$ & $4.4 \mathrm{a}$ & $7.6 \mathrm{~b}$ \\
\hline 509 & 2500 & $22.3 \mathrm{a}$ & $0 / 30$ & $0 / 30$ & $0 / 30$ & $0 \mathrm{a}$ & $7.4 \mathrm{~b}$ \\
\hline
\end{tabular}

* Values followed by the same letter are not statistically different by Duncan Multiple Range Test at 0.05 .

Table III. Extrusion and initiation on media varying in gellan gum concentration.

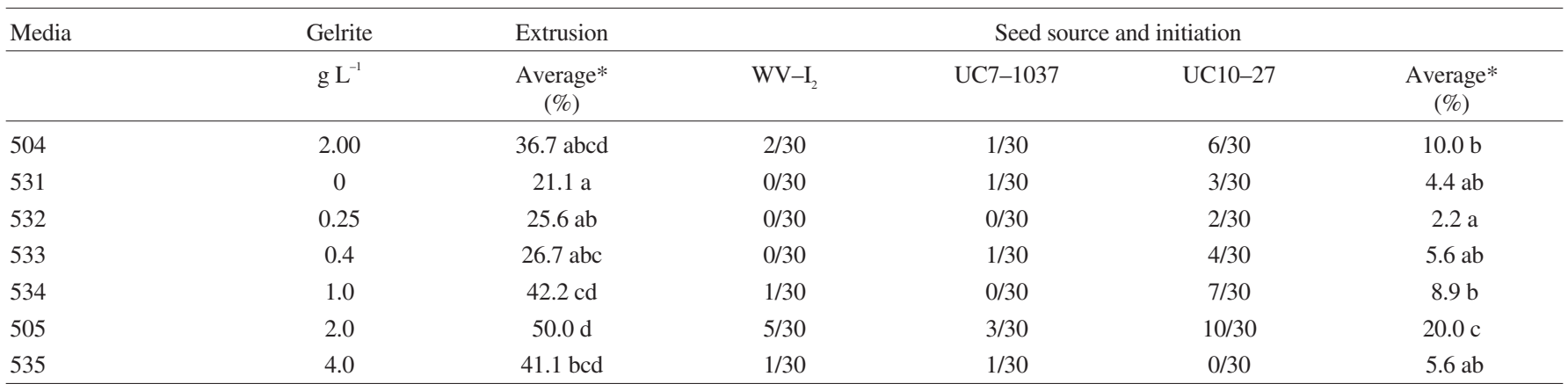

* Values followed by the same letter are not statistically different by Duncan Multiple Range Test at 0.05 .

Table IV. Initiation rates on medium 505 and 539 and six month culture survival for ten open-pollinated families initiated during summer, 1995.

\begin{tabular}{lcccc}
\hline Clone & \# Initiations / total & \% Initiation & \# Survived / total initiations & \% Survival of initiations \\
\hline BC-2 & $3 / 30$ & 10 & $0 / 3$ & $3 / 18$ \\
BC-3 & $18 / 109$ & 17 & $4 / 10$ & 17 \\
BC-9 & $10 / 60$ & 25 & $6 / 25$ & 40 \\
UC5-1036 & $25 / 79$ & 32 & $0 / 3$ & 24 \\
UC7-1037 & $3 / 30$ & 10 & $0 / 1$ & 0 \\
UC10-5 & $1 / 30$ & 3.3 & $2 / 7$ & 0 \\
UC10-33 & $7 / 60$ & 12 & $0 / 10$ & 29 \\
UC10-1027 & $10 / 30$ & 33 & $4 / 12$ & 0 \\
WV-F2 & $12 / 114$ & 11 & $1 / 9$ & 33 \\
WV-I2 & $9 / 60$ & 15 & $20 / 98$ & 20 \\
Overall totals & $98 / 602$ & 16 & & \\
\hline
\end{tabular}

\subsection{Initiation rates and culture survival for multiple families}

Table IV shows a summary of initiation responses for two media, 505 and 539 (table I), varying in gellan gum content of 2.0 and $1.6 \mathrm{~g} \mathrm{~L}^{-1}$, respectively. For ten open-pollinated families initiation averaged $16 \%$. All families initiated cultures with rates ranging from 3-33\%. After six months of transfers every two weeks, 78 of 98 cultures had died. Only $20 \%$ of the cultures survived, representing six of the ten starting families.

\section{DISCUSSION}

For SE Technology to become commercially successful it has to be integrated with breeding programs and has to be successful with a variety of genotypes. To work most effectively with the "leading edge of the breeding program", Timmis (1998) concluded that SE Technology needs to increase the efficiency of ESM (embryogenic tissue) establishment [23].

AC was shown to increase zygotic embryo extrusion from ovules. Somatic embryos formed and began to multiply, but in 
the presence of $\mathrm{AC}>100 \mathrm{mg} \mathrm{L}^{-1}$, growth and multiplication often stopped. This inhibition was partially overcome by supplementing media with extra $\mathrm{Cu}$ and $\mathrm{Zn}$ to compensate for the adsorption of these elements by AC. Copper and zinc are essential elements and are required for plant growth. Both metals are present in growing tissue as structural chelates or metalloproteins and are bound to many essential enzymes [4]. Even with the supplementation of $\mathrm{Cu}$ and $\mathrm{Zn}$, initiation was maximized only when $\mathrm{AC}$ was reduced to levels below $100 \mathrm{mg} \mathrm{L}^{-1}$. One possible explanation is that stimulatory compounds are produced by the female gametophyte during the initiation process. As media AC levels increase, these compounds are removed and unavailable during initiation.

When this research began, initiation rates for LP were often below $1 \%$. Our approach was to study natural embryo development and changes in medium over time. We expected that somatic embryo quantity and quality would improve through imitation of the hormonal, nutritional, and physical environment during zygotic embryo development. Medium 505 was developed through the use of ovule osmotic profile research [15], modeling AC uptake of 2,4-D [24] and research to understand the effect of $\mathrm{pH}$ and $\mathrm{AC}$ uptake on mineral availability $[17,25]$. When tested with ten open-pollinated families, medium 505 initiated cultures at rates ranging from 3 to $33 \%$.

Maintenance of embryogenic tissue from 98 initiations (ovules showing visible somatic embryos) over six months showed a loss of $4 / 5$ cultures. While all of these initiations showed visible somatic embryos initially, many did not grow when transferred to the multiplication medium. In addition, another fraction of the cultures grew poorly for several subcultures and then died. A third fraction of cultures grew well for several subcultures, declined over time, and stopped growing. Literature on conifer SE occasionally mentions the loss of lines during maintenance or the inability to obtain stable lines. However, the magnitude of this problem is rarely quantified or discussed. Tautorus et al. (1991) indicated that $50 \%$ of the Picea mariana suspension cultures tested were discarded due to browning [21]. Loss of LP culture lines after initiation is a significant barrier that needs to be overcome for the commercial use of SE Technology.

Acknowledgments: We thank the member companies of IPST for financial support and Boise Cascade Corp., Westvaco Corp., Weyerhaeuser Co., Union Camp Corp., and Georgia Pacific for cone collections. We are grateful for the help of C. Estes, B. Johns, S. Johnson, S. Ozturk, Y. Powell, and C. Stephens.

\section{REFERENCES}

[1] Becwar M.R., Nagmani R., Wann S.R., Initiation of embryogenic cultures and somatic embryo development in loblolly pine (Pinus taeda), Can. J. For. Res. 20 (1990) 810-817.

[2] Becwar M., Chesick E., Handley III L., Rutter M., U.S. Patent $5,413,930$, Method for Regeneration of Coniferous Plants by Somatic Embryogenesis, May 9, 1995.

[3] Becwar M.R., Pullman G.S., Somatic embryogenesis in loblolly pine (Pinus taeda L.), in: Mohan Jain S., Gupta P.K., Newton R.J. (Eds.), Somatic embryogenesis in woody plants, Vol. 3-Gymnosperms, Kluwer, The Netherlands, 1995, pp. 287-301.

[4] Clarkson A., Hanson J.B., The mineral nutrition of higher plants, Ann. Rev. Plant Physiol. 31 (1980) 239-298.

[5] Ebert A., Taylor F., Assessment of the changes of 2,4-dichlorophenoxyacetic acid concentrations in plant tissue culture media in the presence of activated charcoal, Plant Cell Tissue Organ Cult. 20 (1990) 165-172.

[6] Ebert A., Taylor F., Blake J., Changes of 6-benzylaminopurine and 2,4-dichlorophenoxyacetic acid concentrations in plant tissue culture media in the presence of activated charcoal, Plant Cell Tissue Organ Cult. 33 (1993) 157-162.

[7] Fowke L.C., Atree S.M., Binarova P., Galway M.E., Wang H., Conifer Somatic Embryogenesis for Studies of Plant Cell Biology, Cell. Dev. Biol. 31 (1993) 1-7.

[8] Gupta P.K., Durzan D.J., Biotechnology of somatic polyembryogenesis and plantlet regeneration in loblolly pine, Bio/Technology 5 (1987) $147-151$.

[9] Gupta P.K., Pullman G.S., Method for reproducing coniferous plants by somatic embryogenesis. U.S. Patent No. \#4957866. September 18, 1990.

[10] Handley III L., Method for regeneration of coniferous plants by somatic embryogenesis in culture media containing abscisic acid, U.S. Patent 5,677,185, October 14, 1997.

[11] Handley III L., Method for regeneration of coniferous plants by somatic embryogenesis in culture media containing abscisic acid, U.S. Patent 5,856,191, January 5, 1999.

[12] Li X.Y., Huang F.H., Induction of somatic embryogenesis in loblolly pine (Pinus taeda L.). In Vitro Cell. Dev. Biol. Plant 32 (1996) 129-135.

[13] Li X.Y., Huang F.H., Gbur Jr. E.E., Effect of basal medium, growth regulators and phytagel concentration on initiation of embryogenic cultures from immature zygotic embryos of loblolly pine (Pinus taeda L.), Plant Cell Rep. 17 (1998) 298-301.

[14] Park Y.-S., Implementation of somatic embryogenesis in clonal forestry: technical requirements and deployment strategies, Ann. For. Sci. 59 (2002) 651-656

[15] Pullman G., Osmotic measurements of whole ovules during loblolly pine embryo development, TAPPI Biological Sciences Symposium, October 19-23, 1997, San Francisco, CA, pp. 41-48.

[16] Pullman G.S., Gupta P.K., Method for reproducing coniferous plants by somatic embryogenesis using adsorbent materials in the development stage, U.S. Patent No. 5034326, Issued July 23, 1991.

[17] Pullman G.S., Johnson S., Toering A., Activated carbon adsorbs essential micronutrients: implications for somatic embryo initiation in loblolly pine (Pinus taeda L). Proceedings Conifer Biotechnology Working Group 7th International Conference 26-30 June, 1995, Surfers Paradise, Queensland, Australia, p. 27.

[18] Pullman G.S., Webb D.T., An embryo staging system for comparison of zygotic and somatic embryo development, TAPPI R\&D Division Biological Sciences Symposium, October 3-6, 1994, Minneapolis, pp. 31-34.

[19] Smith D.R., Singh A.P., Wilton L., Zygotic embryos of Pinus radiata in vivo and in vitro, Proc. Third Meeting International Conifer Tissue Culture Work Group, 12-16 August, 1985, Rotorua, New Zealand, p. 21.

[20] Sutton B., Commercial delivery of genetic improvement to conifer plantations using somatic embryogenesis, Ann. For. Sci. 59 (2002) 657-661.

[21] Tautorus T.E., Fowke L.C., Dunstan D.I., Somatic embryogenesis in conifers, Can. J. Bot. 69 (1991) 1873-1899.

[22] Teasdale R.D., Dawson P.A., Woolhouse H.W., Mineral nutrient requirements of a loblolly pine (Pinus taeda) cell suspension culture, Plant Physiol. 82 (1986) 942-945.

[23] Timmis R., Bioprocessing for tree production in the forest industry: conifer somatic embryogenesis, Biotechnology 14 (1998) 156-166.

[24] Toering A., Examining the relationship between 2,4-Dichlorophenoxyacetic acid and activated charcoal in plant tissue culture media, M.S. Thesis, Institute of Paper Science and Technology, May 24, 1995.

[25] Van Winkle S., The effect of activated carbon on the organic and elemental composition of plant tissue culture medium, Ph.D. Thesis, Institute of Paper Science and Technology, May 2000. 